\title{
Skateboarding behind the EU lorry - the experience of Romanian professionals struggling to cope with transition while assisting care leavers
}

\author{
Cu skateboard-ul in urma tirului UE*experienta specialistilor romani in efortul lor de a \\ face fata tranzitiei in timp ce asista tinerii care parasesc centrele de plasament
}

\section{Roxana Anghel \& Chris Beckett}

Correspondence to: Roxana Anghel, Research Officer, Department of Advanced Practice \& Research, Institute of Community Health and Social Care, Anglia Ruskin University, UK. Tel.: 01223363 271, Ext. 2528; Email: r.anghel@anglia.ac.uk; or Chris Beckett, Senior Lecturer, Department of Social Care, Institute of Community Health and Social Care, Anglia Ruskin University, UK. Tel.: 01223 363271, Ext. 2531; Email: c.o.beckett@anglia.ac.uk

As a result of the fall of communism in 1989, the Romanian system of public care for children experienced massive shifts in its structure and ethos. One vulnerable area in any such system is the care leaving stage when young people can fall between the childcare and the adult protection systems. This article draws on a qualitative study that focused on the preparation and early outcomes for care leaving in Bucharest. This was undertaken between December 2002 and March 2004 by Anghel, a Romanian researcher reading for a PhD in England. The research aimed to explore the care leaving process through the views and experiences of the care leavers and the childcare professionals. The article briefly describes the structure and legislative base of the care leaving system in Romania, and discusses the political context created by the EU accession process. It then explores some of the themes emerging from the interviews with the professionals operating the system and discusses them within the overarching theme of transition within transitions: the transition of the young people within the context of transitions simultaneously being experienced by the professionals, the childcare system, and the entire society.

Keywords: Care Leaving; Views of Childcare Professionals; Transition; Romanian Childcare System; EU Accession

Ca rezultat al caderii comunismului in 1989, sistemul de stat de protectie a copilului a trecut prin transformari masive atat ca structura cat si ca filosofie. In orice sistem de protectie a copilului o zona vulnerabila este iesirea din ingrijire, moment in care tinerii pot 'aluneca' printre sistemul de protectie al copiilor si cel al adultilor. Acest articol este bazat pe un studiu calitativ al pregatirii si al consecintelor iesirii din ingrijire a tinerilor ocrotiti in centrele de plasament din Bucuresti. Studiul a fost efectuat in perioada decembrie 2002, martie 2004 de Anghel, doctorand roman in Marea Britanie. Cercetarea a urmarit sa exploreze procesul de iesire din institutii din prisma tinerilor care parasesc institutia si a specialistilor din domeniul protectiei copilului. Articolul descrie pe scurt baza structurala si legislativa a sistemului de iesire din ingrijire in Romania, si discuta contextul politic creat de procesul de integrare in UE. Articolul exploreaza apoi cateva teme rezultate din interviurile cu specialistii din sistem si le discuta in cadrul temei generale a tranzitiilor concentrice: tranzitia tinerilor in contextul tranzitiilor traversate simultan de specialisti, sistemul de protectie a copilului, si intreaga societate romaneasca.

Concepte cheie: Parasirea Ingrijiri; Opiniile Specialistilor Romani; Tranzitie; Sistemul Roman de Protectie a Copilului; Aderarea la Uniunea Europeana

\section{Introduction}

In Romania provision for young people leaving the residential childcare system (care leavers) is newly acknowledged as a problem area, which governmental and voluntary agencies are making active efforts to address. However the transition of the entire system from a communist structure to one in line with internationally recognised standards has a major impact upon the professionals involved in both the statutory and the voluntary sectors.

To some extent there is a parallel between the experience of young people leaving care and that of the professionals, and indeed that of Romanian society as a whole. The young people are moving from an environment that, until not long ago, was a closed system (Zamfir \& 
lonita, 1998, p. 98) in which many suffered physical and psychological deprivations and abuse (UNICEF, 1997, p. 89; Stativa et al. , 2002, p. 35; Stativa \& Anghelescu, 2002, p. 107), but in which the authorities had generallyensured their physical survival. They are moving into an unpredictable, unfamiliar world in which they are required to assume responsibility for their lives and adjust in a relatively short time to new norms and demands. Romanian society itself is making an analogous transition from a system in which the state could be generally relied upon to provide the minimum required for survival and social integration (jobs, housing), even though in many ways acting against people's freedom and quality of life, towards a more Western society in which the rights of the individual are acknowledged, but in which the individuals are expected to assume responsibility for their own lives.

In any country, the transition to adulthood is considerably more demanding for young people leaving public care than for young people in the wider population and in order to succeed they need help in developing appropriate skills and resources. In Romania this help must come from the professionals involved in their upbringing, training and education; but the professionals themselves must deal at work with multiple demands generated by the adjustments that the childcare system is having to undergo under external pressures, and in the context of major challenges resulting from the transformation of Romanian society as a whole. Hence our 'skateboarding behind a lorry' image, where the international community*and now specifically the EU*is the lorry which determines the route and sets the speed, while Romanian childcare professionals, exposed and precariously balanced, attempt to cling on behind.

In this article, based on the findings of a qualitative study, we focus on the views of the Romanian statutory and voluntary professionals who deliver the care leaving service. A subsequent article will look at the views of the care leavers themselves.

\section{Transition within transition}

Children leaving public care in Romania now do so in the context of a political and economic transformation that began in 1990 (Deacon, 1993; Standing, 1996; Lavigne, 2000; Aligica, 2003; Faggio \& Konings, 2003). Within this wider transition, the childcare system itself is undergoing massive structural, philosophical, and cultural changes (Table 1). Within this, and as an integral part of it, the professionals who operate the system have to cope as human beings in an uncertain world.

In order to conceptualise the experiences and the psychological needs of professionals in transition, we will draw on the work of Bridges (1995) and Clarke (1994). Bridges in particular makes an important distinction between change and transition (p. 3 ). Changes can be made at the level of words or on paper very easily and quickly but it is only the lengthy, psychological, and individual (Williams, 1999a) process of transition that translates these into changes at a practical level. For example, it is one thing to change the stated objectives of the childcare system, but only skilled management will result in positive changes that can actually be felt by the young people in the system. Bridges also describes the 'neutral zone' (p. 39), the core European Journal of Social Work 5 Downloaded By: [Swets Content Distribution] At: 21:02 27 February 2007 of transition between the old and the new identities and the most difficult and risky stage. Here the levels of stress, illness, anxiety and staff turnover increase, while motivation decreases, old problems accentuate and people experience contradictory impulses to rush forward and to pull back. Good management of the neutral zone, especially through a large-scale change, is essential for the success of the transition and requires:

- coherent definition of, and structure for, the change;

- information;

- consultation both for learning how things are done in practice and for generating new ideas;

- resources (appropriate training programmes, financial rewards, etc.);

- stimulation of creative thinking and innovation;

- transformation of losses into opportunities;

- feelings of security and identity; and

- a positive outlook on the change. 


\begin{tabular}{|c|c|c|c|}
\hline \multicolumn{2}{|c|}{ Young people's transition } & \multicolumn{2}{|c|}{ Professionals' and system's transition } \\
\hline From & To & From & To \\
\hline $\begin{array}{l}\text { Corporate parent } \\
\text { School or training } \\
\text { Large home }\end{array}$ & $\begin{array}{l}\text { Semi-independent } \\
\text { care and then } \\
\text { personal care } \\
\text { Employment } \\
\text { Small } \\
\text { accommodation } \\
\text { and then unknown } \\
\text { destination }\end{array}$ & $\begin{array}{l}\text { 'Fenced', enclosed } \\
\text { care }\end{array}$ & $\begin{array}{l}\text { Disseminated, } \\
\text { acknowledged } \\
\text { and included (by the } \\
\text { community) } \\
\text { care*although } \\
\text { this transition is not } \\
\text { that much felt by the } \\
\text { current professionals } \\
\text { as many of them } \\
\text { have an average of } \\
\text { only two and a half } \\
\text { years of employment } \\
\text { in childcare, so they } \\
\text { did not have to go } \\
\text { through the practical } \\
\text { and psychological } \\
\text { shift from the } \\
\text { communist system to } \\
\text { the current one }\end{array}$ \\
\hline Adolescence & Early adulthood & $\begin{array}{l}\text { Large, impersonal } \\
\text { institutions }\end{array}$ & $\begin{array}{l}\text { Closure of institutions } \\
\text { and/or institutions } \\
\text { organised in family- } \\
\text { type modules and } \\
\text { day centres }\end{array}$ \\
\hline $\begin{array}{l}\text { Powerless } \\
\text { dependence }\end{array}$ & $\begin{array}{l}\text { Citizenship } \\
\text { (it implies civic } \\
\text { duties as well as } \\
\text { voting rights) }\end{array}$ & $\begin{array}{l}\text { Institutionalisation } \\
\text { as exclusive option } \\
\text { for statutory care }\end{array}$ & $\begin{array}{l}\text { Pressure for } \\
\text { developing } \\
\text { alternative care } \\
\text { (foster care, } \\
\text { national adoptions) }\end{array}$ \\
\hline Care culture & Community culture & $\begin{array}{l}\text { Statutory } \\
\text { monopoly }\end{array}$ & $\begin{array}{l}\text { Community } \\
\text { involvement and } \\
\text { responsibility } \\
\text { (through the NGO } \\
\text { sector) }\end{array}$ \\
\hline $\begin{array}{l}\text { Familiar } \\
\text { environment (for } \\
\text { many*home) }\end{array}$ & $\begin{array}{l}\text { Very new } \\
\text { environment }\end{array}$ & State budget & $\begin{array}{l}\text { Competitive market } \\
\text { created by limited } \\
\text { and prescriptive } \\
\text { international funds }\end{array}$ \\
\hline $\begin{array}{l}\text { Decisions taken } \\
\text { on their behalf }\end{array}$ & Own decisions & $\begin{array}{l}\text { No need for } \\
\text { standards }\end{array}$ & $\begin{array}{l}\text { An avalanche of } \\
\text { requirements } \\
\text { (accountability, } \\
\text { sustainability, } \\
\text { principles of social } \\
\text { work, etc.) }\end{array}$ \\
\hline 'In care' identity & 'From care' identity & Monopoly & Partnership \\
\hline $\begin{array}{l}\text { Identity as part } \\
\text { of a group }\end{array}$ & Identity as individual & $\begin{array}{l}\text { Unique power } \\
\text { holders }\end{array}$ & Power sharing \\
\hline $\begin{array}{l}\text { Corporate } \\
\text { provider }\end{array}$ & Self-provider & Central control & Decentralisation \\
\hline
\end{tabular}


Clarke (1994) reinforces these points and adds that good transition management also entails offering sufficient support and time for adjustment, introducing the change gradually, and seeing the people involved in the change not merely as pawns to push around but as whole people (pp. 56_57).

Both the Romanian childcare system and the country as a whole are currently within the neutral zone, in transit between the values, mentalities, structures, and practices developed during the communist era and those suggested by the Western community.

\section{The context}

Romania has received provisional approval from the EU for accession in 2007. Since its 1995 application, the country has engaged in a strenuous process of change aimed at meeting the accession criteria. One area in which Romania had particular difficulties was that of childcare policy, especially in relation to institutionalised children (Lovatt \& Lovatt, 2001). As a result, the desire of Romania's political leaders to join the European Union leads to the constant generation of childcare policy and legislation, and therefore into pressure on the professionals who are responsible for implementing it.

It is only in recent years that care leavers have been acknowledged as a group in difficulty. During communism care leavers were absorbed by the social protection system, being provided with accommodation, jobs and integration in the community (UNICEF, 1997; Alexiu, 2000), though we know little about their actual experience. Soon after the fall of communism that system ceased to exist. Unless the young person continued his/her education after 18, the state's responsibility was over. Care leavers who were unable to find a niche for themselves in the adult world had limited choices: they could somehow overstay in care (Zamfir \& Zamfir, 1996, p. 261; Buttu et al. , 2001, p. 6); they could try to get onto the limited after-care programmes run by non-governmental organisations (NGOs); they could return to their families where these were known; or they could live on the street.

As of January 2005, the Law on Protecting and Promoting the Rights of the Child (272/2004) allows even young people who are not in education to request two more years of support towards social integration if they are unable to return to their families. However this support can be withdrawn if the young person is deemed not to have made proper use of the employment and accommodation offered.

From 1997, children's homes became the responsibility of a new central government department recently re-named the National Authority for the Protection of Children's Rights (ANPDC) and every local authority area is required to have a specialised service (from January 2005 re-named Directorate for Social Assistance and Child Protection*DGASPC, formerly the DPC*the Directorate for Child Protection) to deal locally with childcare administration and practice. The children's homes became 'placement centres' and institutional care became a last resort, after all forms of family type care had been considered. Currently reform focuses on deinstitutionalisation mainly through family reintegration, and closure of the old, large centres.

Placement centre staff can be divided into care professionals and auxiliary personnel, such as cooks and cleaners. At the bottom of the professionals' hierarchy are the 'educators', the staff who are most in contact with the young person and who most often take on the role of surrogate parents. During the study Anghel found that the educator can have various titles across the centres ranging from simple educator to schoolteacher-educator, professoreducator (OU26/1997), inspector, and referent (Buttu et al. , 2001). Children are organised in groups of 10 or more and each group has two educators working in shifts during the daytime. The educators' status is lower than it was during the communist years as they were formerly qualified schoolteachers but now frequently have no specialised training. Social workers, psychologists, psycho-pedagogues, and medical staff are the next level in the hierarchy. Social workers, usually trained at university level, make links between the child or young person and the community and represent young people during meetings with decisionmakers. Above them are the centre managers, usually coming from a social care background. They are another group who have suffered a downgrade in legal and financial status under the new system. Centre managers can also have a close relationship with the children and young people. They implement required structural changes, ensure that the practice in the centre meets the norms set by the ANPDC, work in partnership with the NGOs that offer various programmes, and can apply through the DGASPC for international funds towards creating care leaving alternatives.

NGOs become involved while the young people are still in care by offering short courses on various issues related to life outside care (i.e. cooking, career advice, CV and job interview 
training etc.), or by paying for young people to take various vocational courses (i.e. to become cooks, waiters, bakers, or mechanics, or to get a driving licence). The NGOs also provide accommodation after care for a limited period, which varies from six months to a year or more.

\section{The study}

This article draws on a wider study carried out by Anghel of the care leaving process in Bucharest as experienced by residents of placement centres in Bucharest, and by the professionals working directly or indirectly with them. In order to make sense of this process some understanding is needed of its 'scaffolding'the structural elements that support, enable or hinder its development, which we have discussed above. Also essential to this understanding are the 'actors', the best source of context-dependent knowledge, which in Flyvbjerg's opinion (2004, p. 422), is the only realistic way to understand social life. In this study the main actors are the young people - but their views will be discussed in a later article. The professionals, the subject of the present article, may be seen as supportive actors.

In 2000, when the preparatory work began on this study, there was very little research evidence on the situation of young people preparing to leave care in Romania (Zamfir \& Zamfir, 1996; Oxford Research International, 1999). Since 2000 children and young people in care have been the subject of some qualitative studies that looked at their culture, skills, and potential for adjustment to independence (Buttu et al. , 2001; Stativa et al. , 2002; Marcovici \& Dalu, 2002; ANSIT, 2003).

Only one of these studies (Buttu et al ., 2001) also researched the views of 20 educators (called 'referents' in that study) about their work and the young people's preparation for leaving care. Buttu et al. record that the educators found their job difficult and emotionally draining, and complained of lack of material resources, overload, and lack of opportunities for career advancement. They felt pressured by the children to offer love and attention, by some parents to give special attention to their children, and by a community whose negativity towards these young people the educators saw themselves as fighting to overcome.

Other literature looked at social workers' stresses and satisfactions (Dickens \& Serghi, 2000a), their attitudes to childcare reform (Dickens \& Serghi, 2000b), and the childcare system's general situation in relation to professionals (Arpinte, 2002). These studies present a picture of a system appearing to promote changes yet lacking standards, vision, prior reflection, consistency, resources, and clear objectives. Dickens and Serghi's questionnaire survey (2000a), which involved 136 respondents ${ }^{*}$ of whom 103 gave their job title as social workers or social work managers from placement centres, DGASPCs, NGOs, and other organisations ${ }^{\star}$ found Romanian social workers lacking in knowledge, resources and guidance, uncertain about the future, and feeling powerless to deal with people's needs and problems. The same survey also found (Dickens \& Serghi, 2000b) that social workers felt that the decentralisation 'had gone too far, too quickly and toward avoidance of responsibility by the government'. They felt that the social services were promoting contradictory measures that cancelled each other out or setting targets that were difficult to meet.

\section{Methodology}

A review of English language research with a similar focus (Godek, 1976; Save the Children, 1995; Festinger, 1983; Cashmore \& Paxman, 1996; Marsh \& Peel, 1999; Stein \& Wade, 2000) and the study's research questions suggested an explorative approach using collective case study design.

The research employed semi-structured interviews as main tools for data collection together with observation, and document consultation. The semi-structured interviews with the professionals were tape-recorded and solicited their views on:

- their roles in the care leavers' lives;

- what they felt the system allowed and did not allow to be provided for the care leavers;

- what they would like to be able to do for the care leavers;

- what they saw as the obstacles and the supporting elements in the process of providing assistance;

- how they saw the relationship between young people and professionals; and

- what suggestions they had for better practice. 
The study benefited from the participation of 18 professionals, 11 women and seven men, who were invited to discuss the care leaving procedures and their experience of working with the young people leaving care. Of these, 11 were from the statutory sector and seven from NGOs. The former comprised three centre managers, two social workers, two educators, one DGASPC representative, and three government representatives. The latter comprised four programme co-ordinators, two social workers, and one counsellor offering support towards employment. Thus a range of views was available from this heterogeneous group.

The study received approval for access from five out of six DGASPCs. The location for the interviews was the professionals' workplaces (placement centres, governmental bodies, or non-governmental agencies), while one governmental official answered the questions through email.

The data collected from the professionals were coded using the QSR NVivo programme for qualitative analysis.

\section{The findings}

\section{Dependence, responsibility and rights}

One striking feature about the comments of both statutory and NGO professionals was their high expectations of young people in terms of establishing independence and assuming responsibility. From an outsider's perspective these views seemed highly unrealistic, even punitive, given what we know of the young people's life experiences so far (Table 2). Yet on the other hand, the attitude of the professionals is also what we might expect from people put in their position, a position in which they themselves are facing extremely difficult demands.

The main perceived problem within the care leaving arena was the dependence that the young people seemed to have developed while in care. The statutory professionals noticed that the majority of the young people who were legally eligible for discharge tried to avoid this by either repeating school years or registering with vocational courses as permitted by the 272/2004 law. This was cited as evidence of a passive attitude on the part of young people and a reprehensible tendency to be dependent on others.

The statutory professionals explained the young people's dependence as something that had been entrenched as a result of early history or even genetics:

[...] they are children raised by so many people they don't have a balance of their own [...] One cannot impose a certain manner on them because that is developed during the "seven years at home" (Romanian expression for the formative early years)....(Social worker)

These generations had been beaten up, as far as I heard from them, maltreated physically and verbally. (Social worker)

[...] and maybe the genetic makeup is also important, and their life story, and the fact that there are cases of segregation in society, of contempt, of discrimination....(Educator)

Many of the NGO professionals were also wary of dependence and some attempted to avoid it by preventing any close relationship with the young people and imposing a formal atmosphere. Others provided information and stimulated young people to develop skills. Partly to prevent dependence and partly because of limited resources, the majority of NGOs also offered relatively short (mainly 6-12 months) after-care accommodation. 


\begin{tabular}{|c|c|c|}
\hline Complaints by professionals & $\begin{array}{l}\text { Professionals' accounts } \\
\text { of own practice }\end{array}$ & Some background \\
\hline $\begin{array}{l}\text { Young people are } \\
\text { ungrateful and } \\
\text { demanding of rights }\end{array}$ & $\begin{array}{l}\text { The professionals say that it } \\
\text { is too late to start working } \\
\text { with the young people } \\
\text { because they have already } \\
\text { formed their personality. This } \\
\text { makes the professionals } \\
\text { uninvolved with the young } \\
\text { people }\end{array}$ & $\begin{array}{l}\text { The current young people are } \\
\text { the children who suffered } \\
\text { extreme physical, } \\
\text { psychological and sexual } \\
\text { abuse (from their accounts } \\
\text { during the study) from both } \\
\text { older children and former } \\
\text { staff (Zamfir \&lonita, 1998; } \\
\text { Stativa \&Anghelescu, 2002) }\end{array}$ \\
\hline $\begin{array}{l}\text { They are not co-operative } \\
\text { and are not involved in } \\
\text { planning for care leaving }\end{array}$ & $\begin{array}{l}\text { Some professionals admit } \\
\text { that they do not make } \\
\text { the best out of the current } \\
\text { resources }\end{array}$ & $\begin{array}{l}\text { They have never had } \\
\text { rights, privacy or personal } \\
\text { belongings. Nobody put } \\
\text { them first }\end{array}$ \\
\hline $\begin{array}{l}\text { They do not retain the } \\
\text { advice that professionals } \\
\text { give to them and do not } \\
\text { trust the professionals }\end{array}$ & $\begin{array}{l}\text { 'Even with the resources } \\
\text { we have we don't give 100\%' } \\
\text { (social worker) }\end{array}$ & $\begin{array}{l}\text { They have experienced } \\
\text { severalmoves from home to } \\
\text { home(Zamfir \& lonita, 1998; } \\
\text { 'Children of Romania' } \\
\text { Foundation, 1998, p. 156; } \\
\text { Tolstobrach, 2000) and many } \\
\text { of them have only recently } \\
\text { met their family }\end{array}$ \\
\hline $\begin{array}{l}\text { They are not responsible and } \\
\text { do not understand that they } \\
\text { need to endure to succeed }\end{array}$ & $\begin{array}{l}\text { The system creates } \\
\text { dependency by not balancing } \\
\text { the give and take and not } \\
\text { stimulating the young people. } \\
\text { Also the current 'give' is } \\
\text { mostly focused on material } \\
\text { resources and does not fulfil } \\
\text { the emotional needs of the } \\
\text { young people }\end{array}$ & \\
\hline $\begin{array}{l}\text { Many young people are } \\
\text { depending on the system } \\
\text { and 'they don't want to } \\
\text { leave' (social worker) }\end{array}$ & $\begin{array}{l}\text { The professionals work } \\
\text { mainly practically and } \\
\text { bureaucratically (their own } \\
\text { complaint), and do not have } \\
\text { time or a supportive culture } \\
\text { for reflection and } \\
\text { psychological work. They } \\
\text { deal with the young people in } \\
\text { care, and expect from them } \\
\text { the same as from any other } \\
\text { young person, in fact even } \\
\text { more }\end{array}$ & $\begin{array}{l}\text { Many of the current } \\
\text { professionals have a work } \\
\text { experience of no longer than } \\
\text { four years (the statutory } \\
\text { professionals interviewed } \\
\text { during the study had on } \\
\text { average two and a half years } \\
\text { of employment in childcare) }\end{array}$ \\
\hline $\begin{array}{l}\text { 'We have young people who } \\
\text { we are proud of, and young } \\
\text { people who refuse to begin } \\
\text { their lives' (educator) }\end{array}$ & $\begin{array}{l}\text { The young people are } \\
\text { expected to be responsible, } \\
\text { but the confusion and the } \\
\text { stress that a move of that } \\
\text { scale creates (Williams, } \\
\text { 1999b), and the individual } \\
\text { pace that everybody } \\
\text { operates within, are not taken } \\
\text { into consideration }\end{array}$ & \\
\hline $\begin{array}{l}\text { They do not understand that } \\
\text { they should 'repay' by leaving } \\
\text { and contributing } \\
\text { to society }\end{array}$ & & \\
\hline
\end{tabular}


NGO professionals explained the young people's dependence mostly in terms of the current practice within the statutory sector:

In the placement centres they have not been educated. (Social worker)

[...] the system induced in them a careless, indolent and passive attitude, making them wait for someone to help, to offer to do something without them taking initiative. (Social worker)

They think that they have lots of rights and very few responsibilities. (Social worker)

They don't have a sense of "enough is enough" and this is, I think, again to do with the education they have received and also about common sense. (Social worker)

They have been in the centre all their lives. (Counsellor)

They could do lots of things but at the same time they are being told "no, don't you do that, we'll do it". (Counsellor)

Strange as it may seem to an outsider aware of the harsh reputation of the care regime in Romania until very recently, one of the main causes of dependency identified by professionals was that young people in care have it too easy. They were seen as being provided with everything they needed and therefore not experiencing the hardships that are typical of family life outside. In the words of one centre manager 'the problem is the lack of problems'. As a result the young people were seen as failing to understand that unless they worked hard and were conscientious and honest, they might not be able to adapt to independence (for example, they would not be able to hold a job). This lack of a sense of reality was seen to make them postpone assuming responsibility for their own care leaving process and thus fail to co-operate constructively with the professionals.

It was also felt that the current care system did not balance provision of services with an equal requirement for contribution from the young people in terms of behaviour, school attendance and achievements, and active search for employment. In the words of an educator 'they refuse the future as well as the present'.

However, while blame was directed towards the care system, this seemed secondary to the criticisms that the professionals made of the young people themselves:

It's up to them to be stable [in keeping a job], they do get counselling. (Educator)

They are used to being given [...] they have it imprinted somewhere in themselves that all that is available is theirs by right, or all you do for them is your obligation. (Social worker)

One solution to this, advocated by a centre manager, might be for the young people 'to experience the hardship of life from 12 or 13'.

Many professionals complained about young people's arrogant 'l've got the right!' attitude, playing 'the victim' and demanding that staff do their duty and serve them. Statutory professionals also expressed feelings of helplessness about their ability to bring about change at this stage. The staff perceived young people as ungrateful and felt that the young people had been given benefits 'all the time', and that this made them difficult. When we put these views against the actual life history that the majority of the young people in care have actually had (see Table 2), the incongruity is striking, but we should bear in mind the professionals' insufficient theoretical and practical training (educators being unqualified staff), the care culture, and the fact that many of the current professionals are fairly new in their jobs (on average two and a half years) and do not know from direct experience the past life of the current young people. We should also bear in mind the unrealistic expectations being made of professionals themselves, which we will shortly examine. 
It would appear that the recent children's rights movement in Romania (first introduced by the ratification in 1990 of the UN Convention for the Rights and the Child and re-emphasised in the new Law on Protecting and Promoting the Rights of the Child) resulted in a significant change of culture in the placement centres when children and young people discovered that they had rights. From the viewpoint of professionals however, the effect seemed to be that young people became disobedient and set a negative example to younger children. The professionals struggled to regain their authority in the absence of the old methods of imposing it through corporal punishment. Professionals seem to feel that the knowledge of having rights unbalanced by a similar knowledge of having responsibilities makes the young people arrogant and ungrateful for the effort that the community makes for them. Some $45 \%$ of statutory professionals specifically said something to this effect, while none said anything to contradict it.

This imbalance between rights and responsibilities was also felt as unfair when contrasted with the situation of other young people in the community. Professionals compared the level of facilities received by young people in care (both materially and in terms of benefits like medical support, regular holidays, and the provision of interesting activities) and those that parents of young people in the community (including the professionals themselves) can afford. And young people in the community, unlike care leavers, were seen to work hard and actually fulfil their responsibilities.

\section{Statutory professionals at time of transition}

The childcare professionals, in common with the rest of the Romanian population, face real hardship and uncertainty outside of work, due to the economic problems and pace of change of Romanian society. Within work they experience themselves as to some extent disempowered and deskilled. They also experience themselves as under pressure from a variety of quarters.

At a structural level they are required to adapt to massive changes in the childcare system, generated by the closure of the large centres. The centre staff feel insecure about the future as they are not informed about or involved in these changes:

[...] we will have to considerably reduce the staff [...] the negative influence begins with the staff member who is scared and transmits this to [the young people]. "What will happen to us?" asks the educator [but] I will not spread information that will change tomorrow. [...] I don't want to disturb them with uncertain information. (Centre manager)

Simultaneously, on a day-to-day level, staff, working with very limited resources and in unfavourable economic conditions, are required to find accommodation and jobs for care leavers:

The old system [...] offered jobs and accommodation, but now this is not possible anymore and professionals struggle on legislatively sterile terrain. (Centre manager)

Professionals, too, have to adapt simultaneously to several different paradigm shifts that have occurred in the last decade (see Table 1). They are expected to speed up deinstitutionalisation and to discharge as many children and young people as possible, mainly through family reintegration, even when this goes against their own judgement as to the young person's best interest.

They are expected to update their knowledge through intensive training, usually provided by NGOs. While some of the training was found temporarily useful, educators felt that, in many cases, the training was inapplicable within real-world constraints.

...I think that those who prepare the courses don't know the reality in the centre and prepare only theoretical courses [. . . ] they should be taught about working in concrete situations ... (Centre manager) 
Another source of grievance was that the training courses 'don't also increase our qualifications and then our salaries' (educator). This is seen as unjust and is also compared with the benefits received by the young people while professionals' own financial situations are sometimes extremely precarious:

...I receive the minimum wage, I am a beginner it's true, but this is awful, what am I supposed to do with this money, almost nothing. If I had to live on my own, I wouldn't be able to survive. (Educator)

Society expects them to produce young people who are adaptable, educated, skilful and independent. However the statutory professionals feel frustrated by the blame that society and some NGO professionals put on them in relation to the care leavers' shortcomings:

Sometimes we are being told off "What are you doing there? We don't want to accept the child because he swears!" [...] There are no ways to express your frustration. What comes back to us is "you are not taking good care of him/her".(Centre manager)

Tensions between the NGOs and the statutory sector create their own frustrations, with NGO staff feeling that young people are sent to them inadequately prepared (one NGO social worker claimed that young people arrive unable even to use a knife and fork) and statutory staff feeling that NGOs have unrealistic expectations:

The social workers in NGOs work with the young person practically, they do something concrete for them, while as social worker in the centre or DPC, we work . . . quantitatively not qualitatively. And there is a subtle conflict. They [NGOs] might say "what exactly do you do for him/her?". (Social worker)

The big problem, when their transition programme begins, is that their files are incomplete. The educators should make notes of their attainments, observations on the young person's progress ... In a [NGO] programme we have to take it from zero and we waste a lot of time. (NGO project coordinator)

The expectations of the NGOs (and of society generally) may be understandable but may nevertheless not match up with the actual facilities, tools and circumstances that professionals have to work with in the centres: the health and safety regulations that forbid young people to work in the kitchen, the policy that imposes discharge before the young people feel ready to leave, the lack of educational resources to assist the staff in working productively with the young people, and even the fact that everything is provided (e.g. food, clothes etc.) so the young people do not have the chance to learn about acquiring things for themselves and making choices:

The food comes from the DPC. The child does not know how much money she or he would need to buy food [. . . ] the children do not know that food can be kept for several days. (Centre manager)

There is no method to touch their soul, morally, I don't know how to make them choose the right path. (Educator)

In addition to the concern about the effect of the children's rights discourse discussed earlier, staff felt that they have not been given tools to replace corporal punishment in helping them to achieve discipline. There appeared to be a tendency as a result for staff not to get involved as much with the children and young people. (Interestingly the comments of young people corroborated this: they complained that nobody got involved with them anymore, that they felt bored and abandoned.) The staff in the centres felt they were accountable by law for the young people's security but yet less able to supervise them effectively. They also felt unprotected, believing that the word of a child would be trusted over that of an adult member of staff in case of allegations of abuse: 
They have fallen into the extreme that the child is always right. First they come to the conclusion and then they analyse. Nothing protects us. (Centre manager)

If anything bad happens it is my fault because I let him out, but you can't supervise him continuously because you get the other reaction "What, are we in prison?". (Educator)

On top of all these pressures the staff felt overloaded and underpaid while the system made their work very bureaucratic, giving them little power and making them feel uninformed and not consulted:

Right now there are too many things to do for the social worker to be able to work on an individualised plan. (Centre manager)

....as a social worker [. . . ] you are not informed, nothing, you are just told off a bit because you haven't got this or that paper in the file. One must cover oneself with paper. I would like better communication and collaboration between line managers and social workers ...(Social worker)

\section{Conclusions}

We mentioned earlier the suggestions of Bridges and Clarke about the preconditions for effective transition (as opposed to purely cosmetic change), but, as can be seen from the discussion above, the Romanian leaving care system is being expected to change in circumstances where most of these preconditions are not present. There is a lack of information, consultation and clarity, there are very limited resources, and there are feelings of insecurity and powerlessness at a very basic level.

This study confirms Buttu et al.'s (2001) findings indicating a cycle of stagnation that the professionals are caught in, and which does not assist the care leavers. However, jaded and 'burnt-out' many of them seemed to be, the statutory professionals seem committed to working in the interests of the young people. They seem to be motivated for change but unmotivated by the current stage in the system's transition. So far the main problems are:

- their current attitudes (passed on to new professionals through the culture in each centre) towards the children and young people, generated partly by the perception that they have to accept sharing their power with the young people. That is experienced as loss of control and de-motivates them from initiating action;

- insufficient knowledge to understand the psychological bases of young people's behaviour;

- insufficient resources like time, training in working methods, and after-care resources;

- lack of training to stimulate reflection and patience when working with the young people;

- lack of consultation about their practice and experience, which makes them feel powerless and unvalued; and

- a general atmosphere of passivity.

While reading the accounts of the statutory and voluntary professionals Anghel was struck by the similarities between the experiences of care leavers and those of the professionals running the care leaving system.

- They both have to face a wider world that is quite unlike the world they are leaving behind.

- They both have a background of poor standards.

- They both are expected to adjust quickly to new rules.

- They both have to meet requirements that they struggle to understand. Young people are expected to find out how to cope independently after a life in institutional care while the professionals are expected to apply Western norms in a society with no legacy of Western values. 
Not only do they have similar difficulties, but, to some degree, their responses are also alike: denial, alienation, passivity, a tendency to expect others to deliver solutions.

What care leavers need in order to succeed in their transition is widely known from numerous studies (see Action on Aftercare Consortium, 1996; Stein, 1997; Vernon, 2000; Broad, 2001; Wheal, 2002, etc.), and there is an expectation that these needs should be provided for by the professionals who work with them. However, in Romania the professionals are part of a population that in a sense is coming out of care itself. Emerging from an enclosed communist system, this could be described as a nation that has come out of care. If the international community really wants to bring about change it will not achieve this by simply stating that professionals and practice should change, or by adopting a punitive approach (Dickens \& Groza, 2004) any more than care leavers would be helped towards independence simply by demanding that they find a home and a job, or by blaming them for not being ready. As Dickens and Groza also highlight, the professionals themselves need to be supported and empowered if they in turn are to be able to support and empower the young people.

\section{Acknowledgements}

The authors would like to thank Steve Rashid, Caroline Currer, and Dave Backwith for their support and advice during the writing of this article. Anghel would also like to thank the gatekeepers who made this study possible and the participants for their welcome, time and valuable contributions, as well as John Moffett and Vanda Florea for their invaluable and continuous support.

\section{References}

Action on Aftercare Consortium (1996) Too Much Too Young ${ }^{\star}$ The Failure of Social Policy in Meeting the Needs of Care Leavers, Barnardo's, Essex.

Alexiu, T. M. (2000) 'Incheierea perioadei de ingrijire', in Assistenta Sociala in Marea Britanie si Romania, ed. UNICEF, Bucharest.

Aligica, P. D. (2203) 'Operational codes, institutional learning and the optimistic model of post-Communist social change', Communist and Post-Communist Studies , vol. 36, no. 1, pp. 87_99.

ANSIT (2003) Culturi alternative si stiluri de viata ale tinerilor din Romania, Bucharest.

Arpinte, D. (2002) 'Situatia personalului din sistemul public de asistenta sociala', Jurnalul de Asistenta Sociala, no. 2.

Bridges, W. (1995) Managing Transitions*Making the Most of Change, Nicholas Brealey Publications Ltd, London.

Broad, B. (2001) Young People Leaving Care*Life after the Children Act 1989, Jessica Kingsley Publishers, London.

Buttu, M., Alexandrescu, E. \& Mihaita, E. (2001) Evaluarea Potentialului de integrare socioprofesionala a adolecentilor si tinerilor, Feed the Children*Romania and USAID, Bucharest.

Cashmore, J. \& Paxman, M. (1996) Longitudinal Study of Wards Leaving Care, Social Policy Research Centre University of New South Wales, ACWA. Available at: http://www.acwa.asn.au/lcwp/publications/excsum.html.

'Children of Romania' Foundation (1998) Cartea Alba a Copilului , The Department for Public Information, Romanian Government, Bucharest.

Clarke, L. (1994) The Essence of Change, Prentice Hall, Harlow. 
Deacon, B. (1993) 'Developments in East European social policy', in New Perspectives on the Welfare State in Europe, ed. C. Jones, Routledge, London.

Dickens, J. \& Groza, V. (2004) 'Empowerment in difficulty`a critical appraisal of international intervention in child welfare in Romania', International Social Work, , vol. 47, no. 4, pp. 469487.

Dickens, J. \& Serghi, C. (2000a) 'Stresses and satisfactions for social workers in Romania and England', Social Work in Europe , vol. 7, no. 3, pp. 14_23.

Dickens, J. \& Serghi, C. (2000b) 'Attitudes to child care reform in Romania: findings from a survey of Romanian social workers', European Journal of Social Work, vol. 3, no. 3, pp. 247260.

Faggio, G. \& Konings, J. (2003) 'Job creation, job destruction and employment growth in transition countries in the 90s', Economic Systems, vol. 27, no. 2, June, pp. 129_154.

Festinger, T. (1983) No One Ever Asked Us: A Postscript to Foster Care, Columbia University Press, New York.

Flyvbjerg, B. (2004) 'Five misunderstandings about case-study research', in Qualitative Research Practice, eds C. Seale, G. Gobo, J. Gubrium \& D. Silverman, Sage, London.

Godek, S. (1976) Leaving Care, Barnardo's School of Printing, Hertford.

Lavigne, M. (2000) 'Ten years of transition: a review article', Communist and Post-Communist Studies, vol. 33, no. 4, Dec., pp. 475_483.

Lovatt, C. \& Lovatt, D. (June 2001) 'Europe to suspend accession negotiations?', Central Europe Review, vol. 3, no. 20. Available at: http://www.ce-review.org/01/20/romanianews20.html.

Marcovici, O. \& Dalu, M. A. (2002) Youth Transitions, Youth Policy and Participation*YOYO, Work Package 2 Report .

Marsh, P. \& Peel, M. (1999) Leaving Care in Partnership*Family Involvement with Care Leavers ,Department of Health, London.

Oxford Research International (1999) Leaving Institutional Care*Romania, provided to the UNICEF Innocenti Research Centre. Available at: http://www.unicef-icdc.org/research/.

Save the Children Fund (1995) You're on Your Own: Young People's Research on Leaving Care, Save the Children, London.

Standing, G. (1996) 'Social protection in Central and Eastern Europe: a tale of slipping anchors and torn safety nets', in Welfare States in Transition, ed. G. Esping-Andersen, Sage, London.

Stativa, E. \& Anghelescu, C. (2002) 'Abuzuri in institutii', in Abuzul asupra copilului in institutiile de protectie sociala din Romania, ed. E. Stativa, UNICEF, Extreme Group, Bucharest.

Stativa, E., Sahan, C., Anghelescu, C. \& Mitulescu, R. (2002) 'Conditiile generale oferite copilului in institutii', in Abuzul asupra copilului in institutiile de protectie sociala din Romania, ed. E. Stativa, UNICEF, Extreme Group, Bucharest.

Stein, M. (1997) What Works in Leaving Care, Barnardo's, Essex.

Stein, M. \& Wade, J. (2000) Helping Care Leavers: Problems and Strategic Responses, Department of Health, London. 
Tolstobrach, N. (2000) 'Sistemul residential de protectie a copilului in dificultate in Romania', in Asistenta Sociala in Marea Britanie si Romania, eds T. M. Alexiu \& C. Selick, UNICEF, Bucharest.

UNICEF (1997) Children at Risk in Central and Eastern Europe: Perils and Promises, UNICEF International Child Development Centre, Florence.

Vernon, J. (2000) Audit and Assessment of Leaving Care Services in London, National Children's Bureau, Department of Health and Rough Sleepers Unit, London.

Wheal, A. (2002) The RHP Companion to Leaving Care, Russell Ho"use Publishing Limited, Dorset,UK.

Williams, D. (1999a) 'Human responses to change', Futures , vol. 6, no. 31, pp.609_616.

Williams, D. (1999b) 'Life events and career change: transition psychology in practice', Paper presented to the British Psychological Society's Occupational Psychology Conference. Available at: http://www.eoslifework.co.uk/transprac.htm\#T1.

Zamfir, C. \& Zamfir, E. (1996) Social Policy ${ }^{\star}$ Romania in the European Context, Alternative Publishing House, Bucharest.

Zamfir, E. \& Ionita, A. (1998) 'Children in institutions', in Toward a Child-centred Society, ed. C. Zamfir, Alternative Publishing House, Bucharest. 